\title{
The Role of Civil Society Organizations in The Face of Contemporary Security and Stability Challenges In Nigeria
}

\author{
Dr. Abdulqadir Sulaiman Muhammad \\ University Of Abujafaculty Of Artsdepartment Of Philosophy And Religions
}

\begin{abstract}
No doubt Nigeria and some continents across the globe are facing serious security challenges ranging from one reason to the other but with almost same agitation of both political or religious sentiment and extremism. One may not be wrong if affirm the link that is between Islamic insurgents splinters groups across the globe when on recent the Nigerian insurgent group (Boko Haram) paid allegiance to ISIS insurgent group which presently creating havoc, maim, massacre and destructions of properties in both Muslims and nonMuslims countries alike in the name of Holy war and exhibition of Islamic teachings and morals. The paper shall therefore debunk and distance Islam with such agitations and also,The paper shall examine the role of civil society organizations in the phase of contemporary security challenges: a global overview, considering Nigeria as the case study, it also highlighted the history of insurgency in Nigeria, insurgent groups, remote causes, the role of an ideal civil society organizations, the role of Muslims clerics, missionaries and scholars. The paper shall also discuss the inevitability of kin relationship between the government, the Ulama'u (Islamic scholars) and civil society in achieving sustainable security, peace and stability, short and long term measures, challenges and sponsorship for civil society shall form the concluding remark.
\end{abstract}

\section{INTRODUCTION}

The origin of present terrorism and insurgency that is bedeviling some part of the world was said to originate after the attack of September 11, 2001, in which 19 militants associated with the Islamic extremist group al-Qaida were said to hijack four airliners and carried out suicide attacks against targets in the United States. Two of the planes were flown into the towers of the World Trade Center in New York City, a third plane hit the Pentagon just outside Washington, D.C., and the fourth plane crashed in a field in Pennsylvania. Often referred to as 9/11, the attacks resulted in extensive death and destruction, triggering major U.S. initiatives to combat terrorism and defining the presidency of George W. Bush. Over 3,000 people were killed during the attacks in New York City and Washington, D.C., including more than 400 police officers and firefighters. The collision were said to cause a massive explosion that showered burning debris over surrounding buildings and the streets below. America was under attack, no doubt America were taken by surprised, which necessitated them to form a formidable forces across the world to strike back. The attack by the terrorist spread to other parts of the world due to the evolving involvement by the American allies when the former President declared war against the world: "either you are with us or with enemy." This statement, necessitated many countries to partake in the war against terrorism, and probably triggered the extension of terrorism to some part of Europe, e.g: Spain, Britain, and France in the recent years.

It should be noted that some Middle east countries were also not left behind in the fight against terrorism which permeated the evolution of ISIS from Al-Qaida down to splinters terrorist and insurgents groups and organizations that are today bedeviling some part of northern, western and Eastern Africa, no doubt, Nigeria is now facing serious security challenges emanated from the aforementioned attack which was believed to be carried by Al-Qaida. ISIS has lost ground in Iraq and Syria to other rebel groups, with help from the US air coalition and Kurdish soldiers, leaders from the Terrorist group has increasingly turn their attention towards Libya and Northern Africa down to western Africa due to the fall of former Libyan leader Muhammad Gaddafi, his fall and the fall of his government led the proliferation of arms and easy movement to many African countries including Nigeria. Now ISIS is using its Libyan base to exacerbate regional disorder and attack Europe and also supporting its splinter groups to perpetrate their evil act.

The proliferation of Insurgent groups across the world were at a results of various indices which include poverty and agitation of youthful exuberance allude with indoctrinations of some itinerant scholars to attain salvation with reward of paradise, no doubt, Poverty is the cause of many of Nigeria's problems. 


\section{SNAPSHOT OF INSURGENCY IN NIGERIA}

Nigeria is at a dreadful precipice. Observers of the country and everyone with any interest in it must be very concerned about what the fallout would be should it be unable to surmount its current problems. The problems are a complex blend of social, political, ethnic, legal and constitutional problems which now bedevil the country in proportions never before experienced in the turbulent and checkered history of this potentially great nation. There is now a dangerous escalation of terrorist campaigns with all the hallmarks of insurgency. Religion may well add to the unending list of Nigeria's woes, as it appears to dominate the essential character of the current campaign of insurgency. Ironically, it could well portend a catastrophe, if not properly managed alongside other instruments of state policy. Nigeria is at the moment at a crossroads. At the end of the day, given the dynamics of the turbulence in the polity, policy choices will certainly dictate whether Nigeria can survive as a state or fail and splinter into fledgling micro-mini states. The indicators are glaring, profuse and ominous.

Boko Haram insurgency, political violence, corruption, nepotism, tribalism, indiscipline, abduction and kidnappings, armed robbery, murder and extortion, bombings of places of worship and innocent Nigerians are all the indicators of a failing state. Nigeria is clearly a nation at war with itself. The path we are treading is a threat to the continued peace, unity and prosperity of this land we call our home ... This is not the Nigeria we inherited from our predecessors, this is not the Nigeria we envisioned as young men. Favoritism, nepotism and tribal sentiments have made it impossible to run a merit driven system. Hard work, brilliance, honesty and integrity in our dealings are no longer rewarded. Rather we celebrate mediocrity soaked in the corruption we claim is our common enemy. I am scared and deeply worried. The situation is grave. ${ }^{\mathrm{i}}$

Ultimately, these social upheavals clearly threaten the survival of the Nigerian nation and we all have a duty to rise and stem the tide.

From the above portrayal, it may not be wrong to conclude with the by saying; that Nigeria is a 'failing'. The situation in Nigeria now has been characterized as getting worse close Mohammed Farrah Aidid's Somalia or, indeed, Yugoslavia following the death of Marshal Tito. The problem is that, if the slide is not checked in good time, the fallout and trauma in the Nigerian case is likely to be worse than Yugoslavia and Somalia put together. To understand what exactly I meant, it is instructive to understand and appreciate each of the phenomena i mentioned. In the process, it will be necessary to answer the question whether, given a failure to abate or mitigate the dynamic interplay of the lethal factors prevailing in the state, Nigeria can survive or will break up as similarly situated countries have historically done. A further question is whether, if the probability of fragmentation is high, there are measures to prevent it from occurring.

However, previous insurgencies in Nigeria have varied in their scope, sophistication and intensity. There have some instances. We need to briefly consider them in turn, based on a rough chronological order, e.g.

\section{DECLARATION OF NIGER DELTA REPUBLIC}

The first known insurgency or terrorism attempt in Nigeria may be credited to the movement to liberate the Niger Delta people led by Major Isaac Jasper Adaka Boro. Major Boro belonged to the Ijaw ethnic extraction in the Niger Delta region and, at the time of his rebellion, was a student at the University of Nigeria, Nsukka. His complaint was against the exploitation of the oil and gas resources of the Niger Delta by both the federal and regional governments in total disregard of the citizens of the area. Boro formed the Niger Delta Volunteer Force (NDVF), an armed military group composed of 150 of his kinsmen. He firmly believed that the people of the Niger Delta deserved a more equitable share of the wealth which accrued from oil. To press the point, on 23 February 1966, the NDVF declared the Niger Delta Republic. The Republic lasted only 12 days before the federal military forces crushed the insurgency and arrested Boro. He and his followers were charged, tried and imprisoned for treason. However, on the eve of the Nigeria-Biafra war in July 1967, General Yakubu Gowon granted them amnesty. Boro enlisted in the federal forces in the war against the rebel Biafran forces of Odumegwu Ojukwu. He died a hero at Ogu, near Okrika in Rivers State, having participated in the successful liberation of the Niger Delta from the Biafran forces. ${ }^{\text {ii }}$

From this episode of Nigerian history, we can identify a number of issues that continue to this day. First, the Niger Delta issue is not forgotten. It continues to be on the front burner in matters of security, insurgency and, indeed, the continued existence of Nigeria. Second, a resurgence of the threat of insurgency will likely re-emerge, either as a response to similar threats elsewhere in Nigeria or where there is a lapse in the policy thrust to remedy the imbalances which caused the insurgency in the first place. This is the background to the emergence of the Movement for the Emancipation of the Niger Delta (MEND) which we discussed above. Third, it is noteworthy that the causative factors in this insurgency are still very much visible in the entire Niger Delta region, namely, extreme poverty in the midst of extreme affluence, degradation of the human living environment to levels requiring concerted humanitarian intervention, discriminatory public policies resulting in political alienation of the human population, unsustainable extractive economies and, finally, the absence of environmental remediation policies and activities. All these, and maybe more, are likely to fuel discontent and exacerbate future conflicts and insurgent tendencies. 


\section{CORRUPTION, NEPOTISM AND TRIBALISM}

The three closely-related phenomena of corruption, nepotism and tribalism are very deeply rooted in the Nigerian way of life. Corruption is any conduct, including verbal and non-verbal communication, which tends to compromise the integrity or to blemish the innocence of the parties involved. This definition, no doubt, raises subjective elements of moral, ethical and cultural context. ${ }^{\text {iii }}$ Both nepotism and tribalism are primordial instincts and are corruptive in that they debase or deprecate the high moral and ethical values which sustain competition in society. They debase the very foundations of any merit system and destroy the competitive spirit and, indeed, do not assist the lofty dictates and aspirations of the work ethic. ${ }^{\text {iv }}$

Nepotism involves acts of favoritism, especially relating to patronage or benevolence by public officials and is directed to various categories of relatives. Such conduct confers advantages, often unmerited, and thereby defeats fair play and denies the competitive rights of similarly situated parties. The public officer's conduct may be said to be monopolistic and thereby distorts competition, particularly when the beneficiary pays for the benefit. Morally and legally, it is a wrong, because it denies others the right to compete. Applied to employment opportunities, it distorts the labor market and thereby disturbs an otherwise even distribution of labor in the market and interferes with the employment of the right personnel for maximal efficiency and productivity.

A tribe is a cultural or ethnic group or sub-group with prominent, identifiable linguistic and other features, sometimes including prominent biophysical ones. Nigeria is reputed to have at least 250 tribes, with an even larger number of ethnic sub-divisions, and over 500 languages and dialects. Tribalism is conduct, particularly of a public official, in a manner that favors inordinately persons or issues which relate to his tribal affiliation. Tribalism is closely related to nepotism in that their economic, political and social outcomes are similar. Both are discriminatory and, therefore, legally unjustifiable as they debase the idea of equal opportunity.

\section{INDICIA OF INSTABILITY IN NIGERIA}

It is necessary to assess each of the indicators to know which, if any, standing alone or in concert with others, has the potential to deal a mortal blow to the continued existence of Nigeria.

\section{1- Political violence}

Political violence is the use of lethal force or other debilitating means by a person or persons against others. In Africa, and particularly in Nigeria, political violence has often occurred in anticipation of, during or sometime after an election campaign. It has been a feature of Nigerian electoral history recorded as early as the pre-independence elections in the 1950s. It is usually intended to eliminate, intimidate, or otherwise subdue political opponents so as to obtain an advantage in the political process. It may have attained its zenith in the early 1960s in the old Western regional elections. The violence in response to the 2011 federal elections, particularly in the northern states, may well be an indication of a resurgence of violence related to the political process in Nigeria. Some Nigerians have described the recent Boko Haram insurgency as primarily politically motivated, though with a religious and ideological color.

Political violence has never contributed to the stability of the state or government. In fact, it is said to have contributed substantially to the failure of Nigerian's First Republic and the emergence of military politics in the country in 1966. For obvious reasons, it abated significantly during military governance but re-emerged with the inception of partisan politics in 1978. It died down again between 1984 and 1998, although there were allegations of political violence during the latter part of military rule from 1994 to 1998 . There has been a visible resurgence since 1999, when the country began its current attempt to move toward democracy. My references regarding the current spate of political violence is the fact that, in all estimations, the intensity and frequency of the violence since 1999 - including murder, kidnapping, extortion and communal violence - has reached alarming proportions requiring urgent attention.

\section{TERRORISM AND INSURGENCY}

Since 2010, or thereabouts, terrorist attacks in the form of bombings of religious and other targets has been increasing at an alarming rate. The point strongly in maintaining:More than ever before in the history of Nigeria, the scourge of terrorism poses great challenges in the Nigerian state. Our slide into anarchy has assumed dangerous dimensions, perhaps beyond the capacity of our security agencies to deal with the menace effectively. ${ }^{\mathrm{V}}$ Although terrorism is not easily defined, it may be said to be the use of force, usually violent, as a means of coercing a target population to submit to the will of the terrorists. Terrorism is intended to elicit or maximize fear and publicity, making no distinction as to combatants and noncombatants in a conflict.There is no legally agreed upon definition of the term 'terrorism', but a recent United Nations (UN) document describes it as any 'act which is intended to cause death or serious bodily harm to civilians or noncombatants with the purpose of intimidating a population or compelling a government or an international organization to do or abstain from doing any act'. vi The word 'terrorism' is both emotionally and politically laden, particularly as it 
imports issues of national liberation and self-determination. ${ }^{\text {vii }}$ Terrorism takes many forms, including political, philosophical, ideological, racial, ethnic, religious and ecological issues. The taxonomy of terrorism, including precipitating motivations and considerations, is now a subject of intense study. ${ }^{\text {vii }}$ Whether the Nigerian experience can be reduced to a type may be an interesting subject, but for purposes of this article, the primary concern is the threat of insurgency. ${ }^{\mathrm{ix}}$ Insurgency is one objective of organized terrorism, just as terrorism is one of several strategies of insurgency. Both terrorism and insurgency may be used by states in their internal and foreign policy operations. Terrorism and terrorist tactics constitute part of the strategies and tactics of insurgency. The operational tactics are essentially those of guerilla warfare. The object is to intimidate, frustrate and raise the feeling of uncertainty, imminent danger and the loss of hope, so as to cripple or limit all aspects of human activity and normal livelihoods. Al Qaida, MEND and, lately, Jama'atu Ahlissunnah Lidda'awati Wal Jihad, (Boko Haram) are currently international and local Nigerian examples of terrorist networks. Until recently, Nigerian terrorist activity was thought to be motivated by ethnocentric considerations. Currently, there appears to be a pronounced religious content in the character of insurgency in Nigeria. A few of the earlier experiences merit examination here, as a guide in estimating the character, trend and intensity of the current campaign, as well as the dynamics and possible consequences.

\section{JAMA'ATU AHLIL SUNNA LIDDA'WATI WAL JIHAD (BOKO HARAM)}

The latest upheaval in the north is Boko Haram which has, without a doubt, the character of an insurgency. The rise of the Boko Haram (meaning 'Western education is sinful') has brought about heightened tension, anxiety and a sense of insecurity hitherto unknown in any part of Nigeria except the Niger Delta region. The group has probably only existed for about nine years. It is based in the northern states of Nigeria and has attacked both the police and military, churches Mosques and other places of worship, schools, international agencies, market squares and other highly-public targets. Newspaper estimates place the number of casualties in the wake of the Boko Haram campaign in the hundreds of thousands, with many others maimed or wounded. The group's weaponry includes bombs, arms and ammunitions of various degrees of lethal capacity. The government is probably doing its best to contain the insurgency, but it is very clear that the task of bringing back the peace and tranquility that once characterized the northern states must be everybody's concern.

\section{PROPHET'S RELATIONS WITH NON-MUSLIMS}

The best way to refute the agitations of Boko Haram and their allies and also to condemned and distance their teachings from Islam is to understand Islamic perspective about the relation between Muslims and non-Muslims is to follow what the Prophet Muhammad said and practiced. Have we can focus our study on the theoretical principles set for Muslims in treating non-Muslims, and in the same way see a practical application of these principles.It is important first to say that most of what the Prophet Muhammad said or did are considered to be legislations for all Muslims. If the Qur'an is the first source of Shari'ah, then the sayings and deeds of the Prophet are the second source. The Qur'an says:

"You have indeed in the Messenger of Allah a beautiful pattern (of conduct) for any one whose hope is in Allah and the Final Day, and who engages much in the Praise of Allah. ${ }^{\prime x}$ One of the main reasons why the golden age

of Islam was one of peace and security was the Prophet's just attitude, itself a reflection of Qur'anic morality.

The justice of the Prophet (SAW) also awoke feelings of confidence in non-Muslims, and many, including polytheists, asked to be taken under his protection. Allah revealed the following request from the polytheists in the Qur'an, and also told the Prophet (SAW) of the attitude he should adopt towards such people: If any of the idolaters ask you for protection, give them protection until they have heard the words of Allah. Then convey them to a place where they are safe. That is because they are a people who do not know. How could any of the idolaters possibly have a treaty with Allah and with His Messenger, except for those you made a treaty with at the Masjid al-Haram? As long as they are straight with you, be straight with them. Allah loves those who do their duty. ${ }^{\mathrm{xi}}$

In our day, the only solution to the fighting and conflict going on all over the world particularly in Nigeria, is to adopt the morality as taught in the Qur'an, and, like the Prophet (SAW), never to depart from the path of justice, making no distinction between different religions, languages, or races. A number of incidents testify to the Prophet's justice. He lived in a place where people of different ethnicity and security challenges. He checks those who sought to spread dissension. One group could become aggressive and even attack another over the slightest word or action.Yet, the justice of the Prophet (SAW) was a source of peace and security for those other communities, just as much as it was for Muslims. During the time of the Prophet (SAW), Christians, Jews, and pagans were all treated equally. The Prophet (SAW) abided by the verse "There is no compulsion where the religion is concerned\} (Al-Baqarah 2:256), explaining the true religion to everyone, but leaving them free to make up their own minds, in the abhorrence of Boko-Haram and their like minds

\section{JAMA'ATU ANSARIL MUSLIMINA FI BILADIS SUDAN (ANSARU)}


Jama'atu Ansaril Muslimina Biladis Sudan, known as Ansaru (meaning 'Vanguards for the protection of Muslims in black Africa'), is a self-proclaimed Islamist Jihadist militant group which is based in the northeastern parts of Nigeria. It was founded in January 2012, when it broke away from Boko Haram. It is reputed to have a more international focus than Boko Haram. Ansaru's motto is 'Jihad fi Sabilillah', which means 'Struggle for the cause of Allah'. This group is still very new and secretive in its operation. It is alleged to have abducted a Briton and an Italian from Kebi State, a French national from Katsina State and, in February 2013, seven French citizens from Northern Cameroon. ${ }^{\text {xii }}$ These kidnappings are the best known of this group's activities in its barely two-year history. More time will be needed to make conclusions as to whether the group's activities are escalating or de-escalating, but need serious attention in order to curtail future security treat similar to Boko Haram.

\section{ESSENTIAL ROLE OF CIVIL SOCIETY}

14. Civil society can play a significant role in helping states increase awareness of the threat and the impact of an attack on local communities, and in deepening public support for government action to address it, which is an essential component of any effective long-term strategy. Terrorism is obviously the state of extreme in human conflict that occurs when the violence enters in the matter. The terrorism is the result of failure in conflict resolution which can occur anywhere in the world. It is the crucial social problem of the society as well. The generally classified and unified roles of civil society in order to preventing and reducing of terrorism are as follows:-

a. Counseling and Educational

b. Community Services.

c. Sponsorship and Research.

\section{COUNSELING AND EDUCATIONAL ROLE}

Civil society organizations can play a momentous counseling and educational role. They can provide policy opinions and proficiency on features of preventing terrorism that is often not obtainable within government. Similarly, civil society experts may provide alternative appropriate language and terminology to public officials in addressing issues related to terrorism and security keeping in view its importance. In order to reinforce co-operation with governments, civil society should also find it appropriate to acknowledge positive steps or measures taken by law enforcement officials and government where they occur. In addition, they may have a positive counseling role in providing tangible substitutes to counter-terrorism policies and measures that they consider to be ill-conceived. It is important to identify and give relevant information to the government in order to understand the real extent of the threat and to be able to provide adequate suggestions of a response and not allow to be gullible. ${ }^{\text {xiii }}$

As for as educational role is concerned, it is very much important for civil society to make clear that human rights are a useful structure for mounting useful counter-terrorism strategies rather than an impediment. Some of the specific activities on this account may include providing information to school students as well as to youth workers and police and law enforcement officials. With regard to the latter, civil society may enter into partnerships with law enforcement bodies to develop targeted programs of co-operation, focusing, for instance, on increasing awareness and understanding of the diversity of communities.

\section{COMMUNITY SERVICES}

It is almost self-evident that civil society institutions can also perform valuable community functions. They have an important role to play as catalysts for the development of opinions and ideas that is vital for building strong and vibrant communities. By creating safe spaces for dissent and by providing a forum where experiences can be shared on a personal level, civil society institutions may contribute to healing community rifts and tensions. They may also consider engaging in outreach activities and taking proactive steps to address the root causes of terrorism. Activities of particular value in this regard are those that strengthen human rights and the rule of law. The promotion and protection of these pillars of democracy contribute to building strong societies in which citizens are free to participate in the political process and exercise their rights. Providing practical and effective support to defenders of human rights is therefore also essential, such should be done in accordance of Islamic right.Another issue which may warrant further examination is the question of whether civil society should attempt to engage in dialogue with individuals and groups involved in and perpetrating acts of violence and "terrorism". For various reasons, it is easier for civil society to engage in such dialogue than for governments. However, Islamic civil society approach is essential in this regard. This includes a clear indication that dialogue does not imply affording any form of legitimacy to the perpetrators of violence.

\section{SPONSORSHIP AND RESEARCH}

Civil society may play a meaningful advocacy and research role. As a matter of principle, it is important that they condemn all acts of violence against civilians regardless of the motivation behind those acts. 
With regard to positive measures in the area of advocacy, they may consider writing open letters and statements to armed groups condemning terrorist tactics and maintaining a principled approach to the applicability of human rights standards, i.e. that these standards apply to both perpetrators and victims of violence. There may be a role for civil society in reducing the emotional and psychological impact of terrorism. In particular, they may engage in activities that aim to amplify the voices of the victims of terrorism and of persons affected by unlawful counter-terrorism operations.

Other aspects of an effective advocacy role include the issue of engaging with the media to shape the public discourse around "terrorism". It is essential for civil society to establish a constructive relationship with the media and the entertainment industry in order to provide reliable information, challenge negative or unbalanced portrayals of parts of the community, and initiate public debate on issues of public security and human rights. At the same time, it is important to encourage debate within the media profession on the image that is conveyed of minority groups in connection with the fight against terrorism and to alert them of their the responsibility to avoid perpetuating prejudices, stereotypes, or inaccurate and/or incomplete information.

Moreover, civil society may contribute high value studies in the field of terrorism, political aggression and for circumstances favorable to the increase of terrorism. High quality studies and research is very important as it reports to helpful and convincing encouragement and prevention efforts. High-quality research may comprise conducting studies and surveys on the impact of counterterrorism measures and on the intricate question of the issues that make persons pledge to radical ideas and engage themselves in acts of aggression. Equally, keeping in view the importance of increase in statistical and monitoring work; civil society can also connect with government in an open and facts-based discussion about the efficacy of counter-terrorism procedures.

\section{CHALLENGES OF CIVIL SOCIETY}

The role of civil society in eradicating terrorism/insurgency is magnanimous but there are many interrelated factors that restrict its freedom of action. Some of these restrictions are discussed as under:-

a. Political Space and Measures Restricting Civil Society. Despite the contributions they are capable of making, civil society groups in many countries lack the capacity, resources, and expertise to engage on counterterrorism issues, while in others, because of lack of political space and measures restricting civil society, civil societies simply do not have the freedom to engage. This ability of civil society to engage is largely tied to basic standards of freedom of information, freedom of association, and freedom to seek funding, which states have an obligation to ensure.

b. Counterterrorism as Exclusively Government Responsibility. The inclination of some governments to view counterterrorism as exclusively a government responsibility and the related "over-sensitivity on the part of security forces and their tendency to consider everything relating to terrorism as top secret" has significantly limited the information flow to civil society, thus inhibiting their ability to gain a full picture of the threats facing and vulnerabilities.

c. Counterterrorism a Crackdown Tool on Civil Society and Political Opposition. In some instances, counterterrorism has been used as a pretense to crack down on civil society and political opposition. A number of successive governments in our country have adopted overly expansive counterterrorism legislation and used it to clamp down on freedom of association, speech, and assembly. The lack of a common definition of terrorism consistent with international human rights standards has made it easier for governments to act this way. More common are subtle forms of state interference including overly restrictive or arbitrarily-applied regulations and restrictions on civil society.

d. Lack of Education and Awareness. The civil societies of the developing and under developed countries are yet to shape themselves to become a resilient part in the power circles of the countries. The main reason for that is the lack of education and awareness of these societies. Since, education is a basic ingredient to generate awareness and sense of responsibility in each person thus its scarcity in masses brings dormancy in the thought processing character of a society. This fact is practically advocated once we peep through the most developed societies of the modern world which have a high literacy rate.

e. Lack of Freedom of Expression. Terrorism most often rises and flourishes in the societies which are either conservative or do not allow the freedom of expression to the masses. This makes the civil society reluctant of speaking freely since they always fear the Government. Thus lack of freedom of speech and expression plays a major role in limiting the role of civil society in tackling the menace of terrorism.

\section{WAY FORWARD}

Although, there are numerous measures that could be taken by civil societies and governments at short/long term levels to overcome the obstacles for deeper engagement, however, a meticulous model has to be crafted by remaining cognize to the peculiar needs of our society in dealing terrorism. More so, a model applied at any point in time should remain flexible to absorb new capacities enabling an all-encompassing approach instead of inducing rigidity and inertia. Few of the suggestions underpinning short and long term measures are as following:- 


\section{a. Short Term Measures}

Developing Awareness and Campaigning. Civil societies need to increase their understanding and awareness of the threat and what is needed to address it effectively. In this context, they should recognize that terrorism does pose a real threat and that it needs to be countered robustly, but within an Islamic right, human rights and rule of law framework. Finally, rather than necessarily creating new networks of civil society groups contributing to countering terrorism, initial efforts should be placed on trying to incorporate counterterrorism into existing ones dealing with related issues, e.g., peace building, Security Sector Reform with a view to avoiding duplication and unnecessary competition among civil societies for limited funding. Moreover, campaigning at different levels will add a great deal to raise public awareness about the viewpoint of the government and military on the fronts. It will also help in curtailing the negative propaganda and psychological operations of Terrorists organizations.

Role of Media. Media being rightly regarded as the fifth pillar of state has a vast role to play in combating terrorism since it is the mouthpiece of both the civil society and the government. Thus, it is essential to establish a constructive relationship with the media being a power bloc of civil society in order to provide reliable information, challenge negative or unbalanced portrayals of parts of the community and initiate public debate on issues of public security. It is important to encourage debate within the media profession on the image that is conveyed of minority groups in connection with the fight against terrorism and the responsibility to avoid perpetuating prejudices, stereotypes or inaccurate and/or incomplete information. Further roles of media in conjunction to the civil society are as follows:-

(a) National Integration. Media should develop National consensus through projection of the view point of government. The welfare works being done in tribal areas should be projected and fairness of the cause addressed. Atrocities of terrorists like burning of the schools in the North East and killing of innocent civilians projected to gain support. War against terrorism should be fought not only as a state but as a society and ultimately national integration will develop as a whole.

(b) National Security. The multidimensional role of the media in contemporary times has made it into an important national institution which along with the Defence Forces can play a significant role in the consolidating national security, provided the media can effectively distinguish between 'Freedom and responsibility'. Media must take all possible measures to ensure that National interest stays supreme and masses acknowledge it as such. Causalities especially of armed forces must not be in any case blown out of proportion.

(c) Improvement of Military - Media Relations. There is a need for reporters to be educated about the military and the military about the media. Technology has had a tremendous impact on media. It must be assimilated. News media and military media should jointly engage in a study of the security issues posed by real time reporting from the battle field.

(d) Administrative Measures. In regards to Nigeria, there is a dire need of making immense number of administrative improvements in order to avert the increasing ratio of terrorist sympathizers in Muslims dominated areas. These state requires an immediate overhaul in order to develop a sense of belonging. Moreover, a concurrent effort should be made to provide every possible facility to the people of these areas ranging from food, health, shelter to education and employment. An endeavor should be made to convert these areas into a society of peace and justice. This is the only way that we can manage to develop a reformed civil society in those areas which will itself avert the rise and growth of terrorism. Apart from this, certain steps required to be undertaken at country-wide level are as under:-

(a) A well-conceived de-weaponization campaign may be launched throughout the country.

(b) Merit and professional requirement should decide posting of police and military officers down to police station level. Undue interference from any quarter should be discouraged.

Aid for Social Uplift. The need for a more integrated and coherent approach to development and security does not justify the "slow bleeding of financing for development purposes into security-related military activities," Nor does it mean that all development and security goals are compatible. Development can contribute to security, but only if the integrity and autonomy of development activities are respected fully. The development of social projects in the field of health, education and employment can contribute in reducing uncertainty and terrorism. The lack of funds and flexibility in their usage also narrows down the role of civil society circles in different fields. Thus apart from funding and raising the security infrastructures, the aid must be aimed at development of the society and population through the hands of civil society.

Reforms in religious teachings and Seminars. Nigeria observed too much freedom in discharging religious activities, this research deemed it necessary to regulate preaching teachings and seminars, and such should be done under the auspices of the highest religious body (Supreme Council for Islamic Affairs and Christian Association of Nigeria). However, following few steps suggested in this regard are as under:-

(a) All Madrassas (informal schools) should be registered and a proper check and balance of their pupil and financing should be done by the government or Registered religious organization.

(b) All Madrassas found involved in militant activities should be immediately banned. 
(c) Foreign funding to Madrassas should be thoroughly checkmate and state control should be exercised to enforce scrutiny and audit of all funding.

(d) A Counsel of National Integration comprising eminent religious scholars from all sects be constituted to rationalize syllabus all over Nigerian giving due consideration and respect to beliefs of all sects.

(e) The syllabus should also include science/ art subjects as taught in government institutions.

Educational Measures. Prevalence of general illiteracy and ignorance to correct teaching of Islam is one of the main reasons of extremism and terrorism in Nigeria. This is an aspect that can be vastly cured by the steps and initiatives of the civil society with cooperation of the Nongovernmental and governmental Organizations. Many steps can be taken which can help in de-radicalization of the certain circles of the society and hard core terrorists. These educational projects and campaigns should be aimed at the under developed areas of the country targeting the children of the lower class society in order to save them from falling prey to radicalization or making militancy as a source of income. Free and Quality Islamic education can do miracles to combat terrorism. Following measures are suggested to eradicate the ills:-

(a) Free and mandatory education up to matric for all.

(b) Lessons on basic tenets of Islam may be included in every schooling system.

(c) International Islamic Universities may be consulted to improve various syllabus periodically.

(d) A nucleus of well-educated Islamic teachers may be created, first at provincial level, and then expanded to district level, for imparting Islamic education to prospective Imam Masaajid (Mosques).

(e) Islamic education teaching institutes may be established accordingly.

(f) Religious Measures. The role of religious scholars in a conservative society like the North East is magnifying. The preaching of religious and sectarian harmony in masses should be done. The government should lay efforts to form an effective Civil Society Council which should have representatives from all the factions and religions in the country to deal with issues on community basis thus, increasing the stakes of the Civil Society in the country. This would not only be a symbol of a true community but would also add to national cohesion. Apart from this, a few steps that can be undertaken are as following:-

(a) Religious scholars must preach sentiments of love, fraternity and human values of tolerance, mutual respect and equality in their sermons and addresses.

(b) Approved Khutbaat (sermons) with consensus for issuance to Khateebs / Imams of all mosques/ down to village level. Government should enforce these recommendations in collaboration with highest religious bodies in the country.

(c) Nigerian Government should regulate preaching of all kind, this should be enforce through the highest religious body in the country i.e. Supreme council of Islamic affairs and Christians Association of Nigeria (CAN) as mentioned above. The research also commended the effort of Niger state Government and recently Kaduna State Government for taking such noble step.

\section{CONCLUSION}

The civil society in close ranks must stand to understand and materialize its due role in combating terrorism. Given simply, civil society is the core ingredient in creating conducive environment for all elements of national power to tackle the menace of terrorism with a cohesive and unified approach. Task is indeed gigantic than the words can describe given the peculiar order of our society vis-à-vis deeply seated, fundamentally porous and widely divergent perceptions of the masses to accept their responsibilities. However, a start even with primitive designs will eventually prove fruitful in shaping our society's landscape to mitigate those potentials and indicators that presents opportunity for terrorism to make ground. On the whole, civil society should work as a catalyst to curtail terrorism. They should endeavor to identify the region, specific causes of terrorism through in depth social researches and should work with the masses, social groups and governments to diminish the terrorism from the society.However, is of no doubt that different set of militants group have emerged in Nigeria with Boko Haram leading the prawn. It has been established that insurgence of Boko Haram have posed serious challenges to this Nation which have been briefly highlighted without neglecting factors that instigate militancy insurgency in Nigeria which latter concludes with recommendations towards avoidance of future militancy insurgency. It could be recalled that the main drive behind formation of all this ethnic militant are social injustice, marginalization, neglect, deprivation and seeming insecurity for the people. And I belief that Boko Haram were have early been used by some foreign forces on one hand and by Northern Politicians as a political militia on the other hand but the group subsequently move out of their control and constitute threat to the whole Nigeria. No wonder Ambassador Yusuf Mamman (Vanguard Newspaper, 2011) stated that you cannot separate politicians from this because whether bombings were done by militants of the Niger Delta or Boko Haram or any armed group in Nigeria, politicians have a hand in it. Many armed groups are sponsored by politicians.

\section{WORKS CITED}


[1] D. Mustapha. '’Media and Democracy', National Mirror 21 December 2012 1-2

[2] Odumegwu Ojukwu' Wikipedia http://en.wikipedia.org/wiki/Odumegwu_Ojukwu (accessed 31 January 2014).

[3] The Term Corruption is defined loosely by the corrupt Practices and other related Act (2004) as concludes bribey, and other related offences

[4] Ibid bid

[5] UN Secretary-General Ban Ki-Moon, Keynote Address, Closing Plenary of the International Summit on Democracy, Terrorism and Security, 'A Global Strategy for Fighting Terrorism' Madrid, Spain, 10 March 2005.

[6] CFD Paniagua 'Negotiating terrorism: The negotiation dynamics of four UN counter-terrorism treaties, 1997-2005 PhD thesis, City University of New York, 2008.

[7] See the Declaration on Measures to Eliminate International Terrorism annexed to UN General Assembly Resolution 49/60, Measure to Eliminate International Terrorism UN Doc A/Res/69/60, 9 December 1994. See also R Bailey 'Earth liberation front terrorist gets 22 years in prison for anti-biotech arson' Reason Magazine http://reason.com/blog/2009/02/06/earth-liberation-front-terrori (accessed 31 January 2014).

[8] See PP Purpura Terrorism and homeland security: An introduction (2007).

[9] Al Hilali, M. T. and M. M. Khan, The noble Qur'an English language, Al-Ahzab: 21

[10] At-Tawbah 9:6-7

[11] See H Idris 'Why we abducted French nationals' Daily Trust 19 March 2013 7. See also T Badawale 'The rise of ethnic militias, de-legitimisation of the state, and the threat to Nigerian federalism' (2001) 3 West Africa Review 1-11.

[12] See M Weber The Protestant ethic and the spirit of capitalism trans T Parsons (1930).

[13] International Journal of Scientific and Research Publications, Volume 3, Issue 11, November 20137 ISSN 2250-3153 